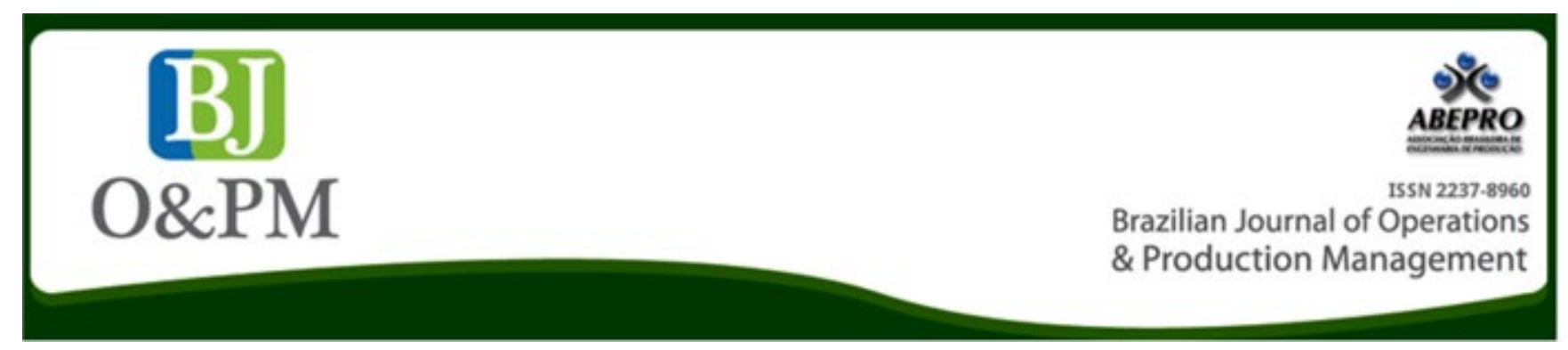

\title{
ACADEMIC COMPETITION FOR PROTOTYPE DEVELOPMENT
}

Rubens Aguiar Walker rubens.walker@gmail.com Grande Rio University UNIGRANRIO, Duque de Caxias, Rio de Janeiro, Brazil

\section{Ruben Huamanchumo} Gutierrez

rubenhg3000@gmail.com

Fluminense Federal University -

UFF, Niterói, Rio de Janeiro RJ

\section{Marcos dos Santos}

marcosdossantos@ime.eb.br Military Engineering Institute IME, Rio de Janeiro, Rio de Janeiro, Brazil

\section{Natálya Regina Guimarães} Pereira

natalyaguimaraesp@hotmail.com Grande Rio University -

UNIGRANRIO, Duque de Caxias, Rio de Janeiro, Brazil

\section{Marcone Freitas dos Reis} marconefreis11@gmail.com Technology Center for the Chemical and Textile Industries, National Service of Industrial Learning SENAI/CETIQT, Rio de Janeiro, Rio de Janeiro, Brazil

\begin{abstract}
The purpose of this article is to describe a development method in academic to designing products by industry management in a competitive and collaborative manner. The focus is to create toys for donation in a competitive project so the students get more involved with the purpose to learn. The developed method was a competition using recycled materials in a sustainable way. The final toys donation creates a delivery to the society, generating added value for the students. The findings are dynamic due to the increase of each semester, obtaining a better academic yield by the combination of theory and practice. The contribution is defined in the delivery of skills to the industry of competitive students for the job market, generating innovation without an expensive research process.
\end{abstract}

Keywords: Product Development Process Education; Prototype. 


\section{INTRODUCTION}

The development of a product consists of the set of activities through which it is sought from the needs of the market and the technological possibilities and constraints, considering the company's competitive and product strategies, and if it reaches the specifications of a product's design and its production process, so that manufacturing can produce it and monitor the product. After the introduction of the product on the market, it is necessary to make some changes in the specifications to adapt it to the market. Thus, the product is not discontinued early and the lessons learned are incorporated in the process development through the product life cycle.

This development is considered a business process that is increasingly critical to the competitiveness of companies. Especially with the increasing internationalization of markets, increasing diversity and variety of products, and reduction of the life cycle of products on the market, new products are demanded and developed to serve specific market segments, to incorporate diverse technologies, to integrate with other products and uses, and to adapt to new legal standards and restrictions. It is through this process that the company can create new products that are more competitive and in less time to meet the constant evolution of the market, technology and requirements of the institutional environment (mainly health, environment, and safety).

Customers are becoming more demanding, informed and with greater possibilities of choices. Global competitor companies often launch new products that seek to continuously respond to changing customer needs in the best and most functional way, making them more attractive and generating the customer's desire to replace the previous product.

This competitive environment imposes on the product development process the need to be able, in terms of skills and competences, to act with dynamism and flexibility in a degree not previously experienced by companies.

\section{UNIFIED MODEL OF PRODUCT DEVELOPMENT PROCESS}

It is a generic model that contains a set of best practices on Product Development Process (PDP) structured in phases and activities. This model depicts all the stages of the process and describes the activities with its input and output information, tasks and related best practices.

It aims to generate a possibility for the reader to know and study the PDP, and it can apply it in a company. The PDP model can be used to diagnose the management process in the product development.

The term "best practices" refers to all types of knowledge that can make a PDP activity or task faster, with reduced time loss, and minimizing costs.

This unified model:

- Produces structured documentation of PDP best practices;

- Proposes the integration of several PDP methods, tools, systems and concepts;

- $\quad$ Provides learning support related to product development;

- $\quad$ Serve as a reference for the standard process definition for companies, for detailed studies and for benchmarking.

- For those who wish to improve the reference model of their company, they can:

- make a previous research in order to know the best practices;

- Compare the current situation of their company with the best practices of the model;

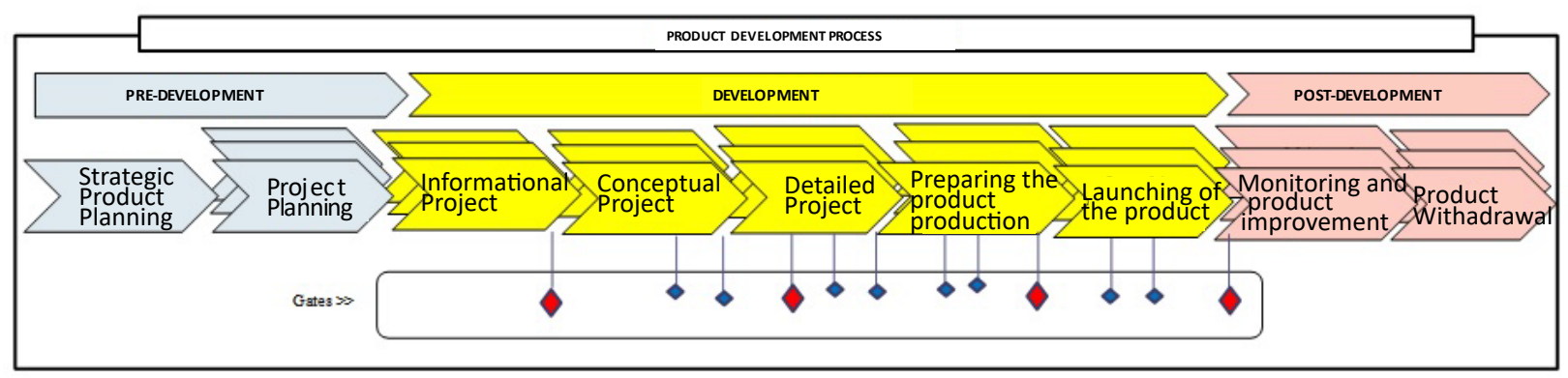

Picture 1. Unified Model of Product Development Process, Source: Adapted from Rozenfeld et al. (2006) 
- Define the practices to be applied;

- Define the standard process of their company.

\section{PROBLEM}

Industries are trying to be more compatible and to improve a country's economy. Developing technology seems to be the key and needs a lot of investment on higher education in research and development. Engineers regard training as the most important phase to learn, but they forget that Sciences and Mathematics are the basis for developing products and technology (Li, 2015). Somehow, the skills to develop solutions have not been reached and Engineering and education do not show how to think about the problems ahead, only to expose information.

Creating solutions can be the key for improving the ability to develop sustainability. Bringing knowledge, the best products and ethical attitudes is related to most of the activities that can be developed within classroom. The education that "shows" the way may be less effective in the case of development than problems that are the basis for learning and developing challenges, thus enabling students to have the capacity to create solutions. Teaching how to correct a problem that does not yet exist for a new professional is an academic challenge. The PDP model was successfully adapted to be applied in the classroom for an undergraduate engineering course.

To validate the work structure, deliveries must be specific in the form of:

- Creating a model for the improvement of ideas;

- Creating a prototype of recyclable materials for sustainability development;

- Involving students as professionals to work together to create and develop new sustainable solutions without a sponsor.

\section{METHODOLOGY}

The development of the problem was accomplished through the exploration of the bibliography in order to create a qualitative model. Data exploration was introduced into the construction of classroom practice for theory learning. The classes were exploratory and were created through the reading of the bibliography and creation of problem situations. The idea of toys was created through brainstorming with other professors. The competition came from the observation of LEGO robot competition. The method has been continuously improved according to the results achieved with the following stages:

- Exploration - Class feedback through students' discussions to develop ideas. During the end of each class cycle, students gave their contribution by criticizing the current method. Professors make notes and develop ideas to introduce in the following semester.

- Prototyping - The basis for creating a prototype came from Rozenfiel et al. (2006). The stages were adapted to replicate an industry environment. The motivation is the development of a toy that is going to be donated to poor children.

- Evaluation - A competition is the last stage to validate the product. External judgers measure the product innovation, viability and finishing. Each criterion provides a grade to students. The group that has the higher score can win if they collaborate and make all the deliveries on time.

\section{CASE STUDY}

The case study presents an adapted model of Rozenfeld et al. (2006) to develop prototypes in the classroom. In this case, there is a restriction, as the last step of the market launch was replaced by the donation of the toy to needy children, with the objective of creating an ethical commotion in the members to generate value to society.

\subsection{Unified model in education for prototyping}

The teaching approached has, as its first step, the development of a model and the second the development of a prototype. The first stage consists of a drawing with a scale model developed in cardboard, or Styrofoam, or any cheap material. The second delivery is the functional prototype.

Eight tools will be developed in total. The first is Brainstorming carried out in a structured way, with the real example of a cell phone. The goal is to get students to collaborate and transform them to generate productive ideas. The second is to show how to copy or adapt ideas by means of reverse engineering using the black box technique. The third is the translation of the features and its comparison using the Quality Function Deployment (QFD). The fourth tool consists of assembling the model in cheap material with its design and bill of material. At this point, the models are evaluated for the continuation and construction of the prototypes. To make a prototype it begins by defining the engineering requirements, material to withstand the efforts, the electrical 
Brazilian Journal of Operations \& Production Management

Volume 15, Número 4, 2018, pp. 481-489

DOI: 10.14488/BJOPM.2018.v15.n4.a2 part to drive electronic mechanisms, development of fluid mechanics and thermodynamics, following the research of the standards applied to the product. The Engineering features are evaluated by the TRIZ method to be improved by means of existing solutions. In defining the dimensions and materials, DFMA is very useful for adjusting the product, manufacturing, and assembly. Finally, a cost evaluation is made to represent the possibilities of this in the market. The basis is the representation of the stages of development of the process.

\subsection{Brainstorming}

The example developed is an electrician ladder that needs to reach four meters and be portable to open a discussion of ideas. The first model is exemplified in Picture 2. The professor guides the students that need the following requirements: insulation materials, base, non-slip, foldable, fitting and durable material, and lightweight material, followed by details such as: wood, rubber, aluminum and their relationships with each other.

Then the students prepare to compete with the professor in a game of motivation in the creation of a cell phone. The cell phone has to serve the young public and has to be cheap and simple. The delivery of the result in 3 hours is representative for a trained instructor, but it unites the class to start the projects.
Then the requirements are related and integrated from their understandings for the creation of a toy.

\subsection{Black Box or Reverse Engineering}

The black box is a tool whose function is to relate inputs and outputs and transformations between them. It is a graphical representation of what is being designed to a system or an object. The entrances are set on the left side of the box and the exits from the right side. All these inputs and outputs must be specified. When assembling the black box, the designer can ask questions, such as "What happens to this entry?" or "Where does that exit come from?" These questions can be answered by removing the lid from the black box and turning it into a transparent box to see what goes on inside, as observed in a drill black box in Figure 3 (Dym et al., 2009).

This method can be quite efficient for determining functions. Its only requirement is that all inputs and outputs must be identified (Dym et al., 2009). Sanches da Silva (2005) apud Silva (2014, p. 116) describe that Reverse Engineering is a technique of "developing, improving, perfecting or adapting products". The aim of the reverse engineering of the drill would be to identify the main sub functions that are performed by the main subsystems that are required to obtain the basic drill function (Dym et al., 2009).

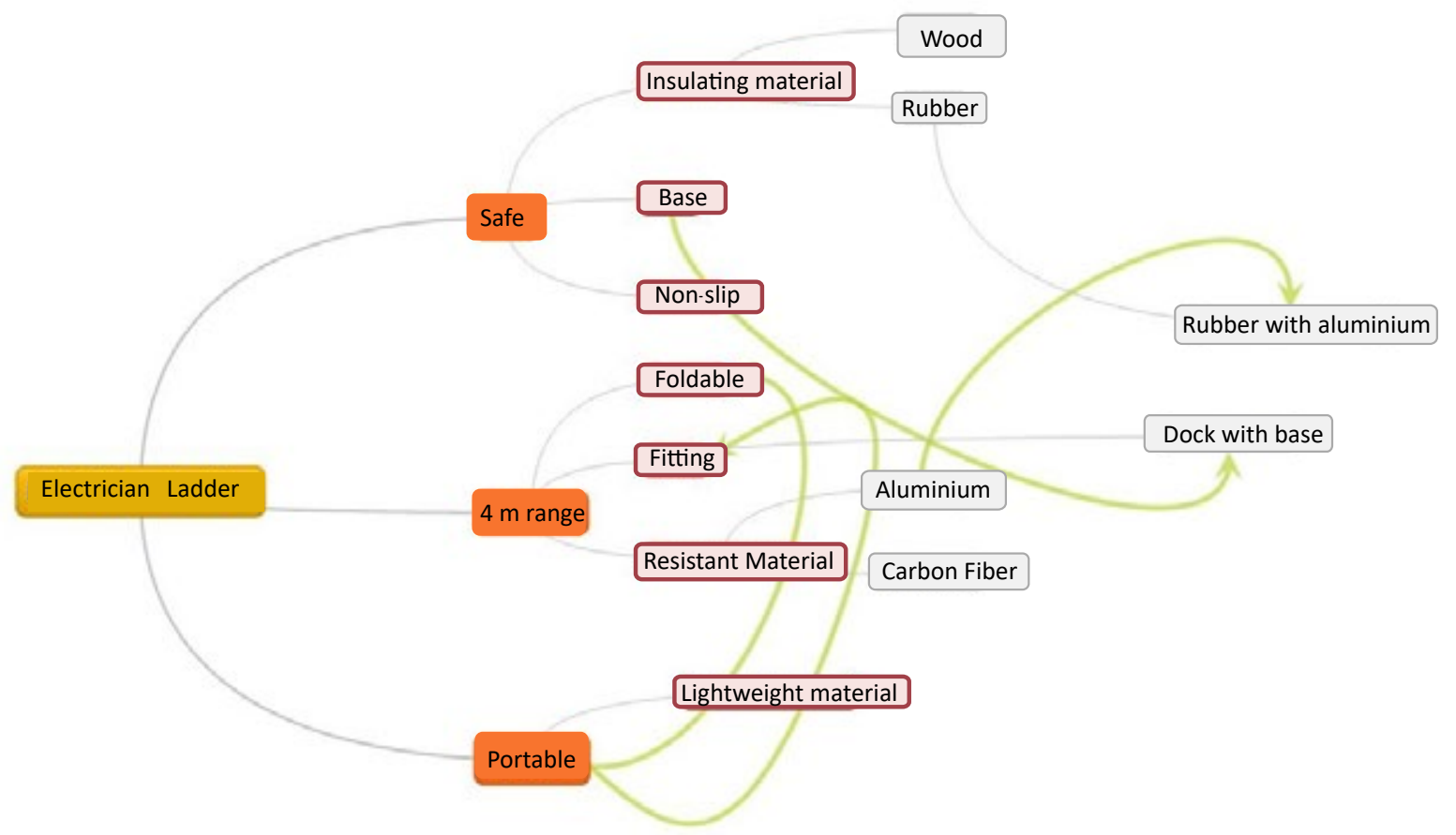

Picture 2. Brainstorming Electrician Ladder 
In the classroom, a LEGO 3177 kit is used to develop the black box. Where students are forced to redesign the assembly process with the functionalities of a toy cart.

The abstract value becomes viable in the presentation of the problem and one can create reverse engineering in practice to analyze other products in looking for details with the disassembly of the LEGO toy. The goal is to generate to students the existing research tool instead of creating a new one.

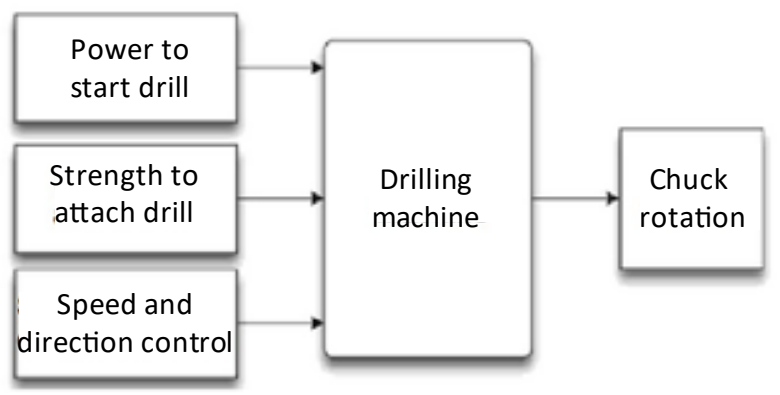

Picture 3. Black box of a Drilling Machine, Source: Dym et al. (2009)
These output values represent the input and output features to be joined in QFD requirement analysis.

\subsection{QFD}

Quality Function Deployment (QFD) is a technique used to implement strategies to meet customer needs (Chowdhury and Quaddus, 2016 apud Santos et al., 2016). These needs can be deployed in the delivery and quality of the project, for the product / service, through a matrix that has information and data that is necessary to obtain good quality. The QFD's purpose is to focus on the items that are more important to the customer and to the company, which will make available a mechanism that will provide competitive advantages (Miguel, 2003 apud Santos et al., 2016). The QFD is a dynamic tool that involves the entire company (Perotti et al., 2009 apud Santos et al., 2016) and that produces. For each of the quality features, this is a specific characteristic that the product / service can contain (Miranda, 1995 and FNQ, 2008 apud Santos et al., 2016). This technique is mainly related to the stage of the product development cy-

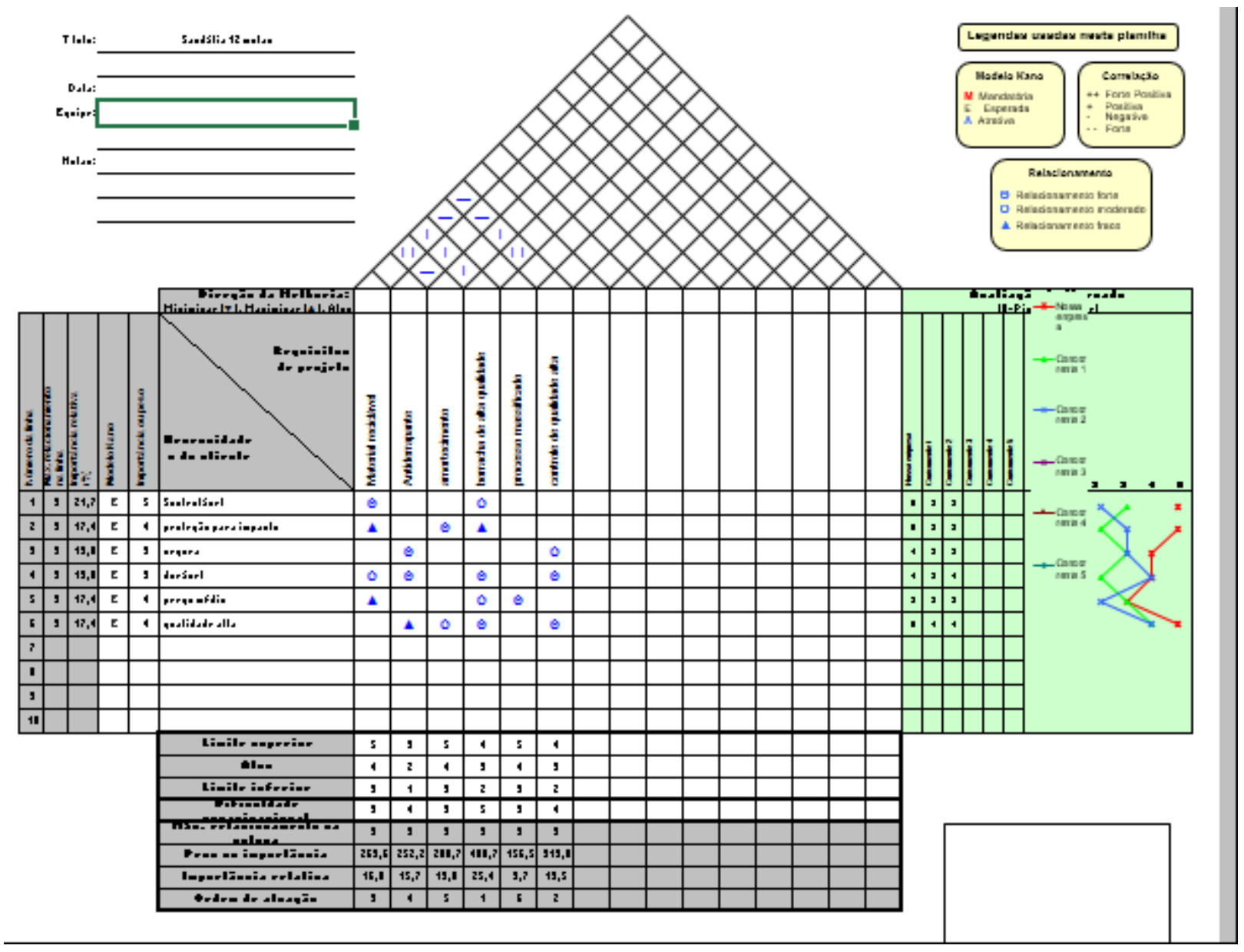

Picture 4. QFD example 
cle and its planning in the company (Cheng and Filho, 2010 apud Santos et al., 2016).

The features are aligned and divided into two tiers. The first "What" is represented in the brainstorming data entry and the black box; the second is the output of these data in the "as" requirement. In Picture 4 it is possible to observe the interaction of students with the technique for developing the case study and the practical project applied.

The Kano model is highlighted to identify the quest for requirements and comparison in the market. With these details, students can design and make the product structure of your project.

\subsection{Product Design and Bill of Material}

Drawing is very important for product design; however, a physical model, with cheap material, can represent the design on a smaller scale. This is the great delivery for early criticism. Schlender and Tetzeli (2015) mentioned that Steve Job from Apple organized weekly meetings to validate product models and turn them into projects. Picture 5 (Peinado and Graeml, 2007) represents the delivery of the student's drawing from a created model.

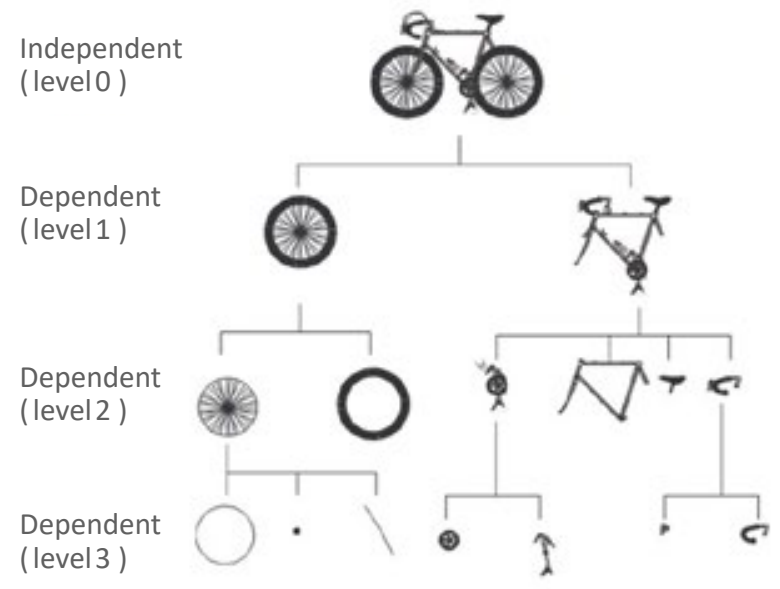

Picture 5. Bill of Material example, Peinado (2007)

The bill of material is very important for the definition of purchases, production planning, raw material flow, and semi-finished product on the factory floor. The understanding of assembly and fabrication depends on the design plants that are represented by this set.

\subsection{Engineering Features}

Engineering Features are represented by structural calculation, material, electrical circuits, and others. The most presented technique is the Value Engineering, represented by Rosenfeld et al (2006). Its application is necessarily linked to the indication of what is important to calculate. In many cases, as the painting can be toxic to a child on a toy, it represents a value for this feature. The best way is to meet the experts and then structure the standards to be followed. With the data, many features are calculated in the CAD software itself as SolidWorks does.

\subsection{TRIZ Methodology}

Engineering features requirements can be a big problem. An example is when a product needs a lightweight and sturdy material. TRIZ Methodology is a set of several methods that establish a solution standard for the incompatibilities of the engineering features. (Gomes Filho and Rautenberg, 2015). This methodology improves systemic innovation to search for solutions to the current engineering requirements problems.

TRIZ theoretical basis are the evolutionary patterns of technological systems that can be used to solve complex problems (Fernandes, 2013) to predict the evolution of systems, and to create or improve tools that are used for solving problems.

TRIZ model results are the standardized requirements of engineering resources. The system simplifies the acquisition of knowledge when there is difficulty for calculating the technical parameters. The end of this process is a robust product design. The next stage are the needs for manufacturing and assembly.

\subsection{DFMA}

The Design for Manufacturing and Assembly (DFMA) technique is used in the development and improvement of a product. Its goal is to promote greater ease of manufacturing and cost reduction by developing a product that has all the functional requirements. DFMA generates several benefits to the final product, such as improved quality, reliability, and significant cost reduction in production, for example (Barbosa, 2012).

For Boothroyd et al. (1994) apud Barbosa (2012) this technique should be more used at the beginning of the conceptual phase of a project, because modification costs are lower and the project lifetime is lower at this stage. The phases of the DFMA can be seen in the picture 6 . 


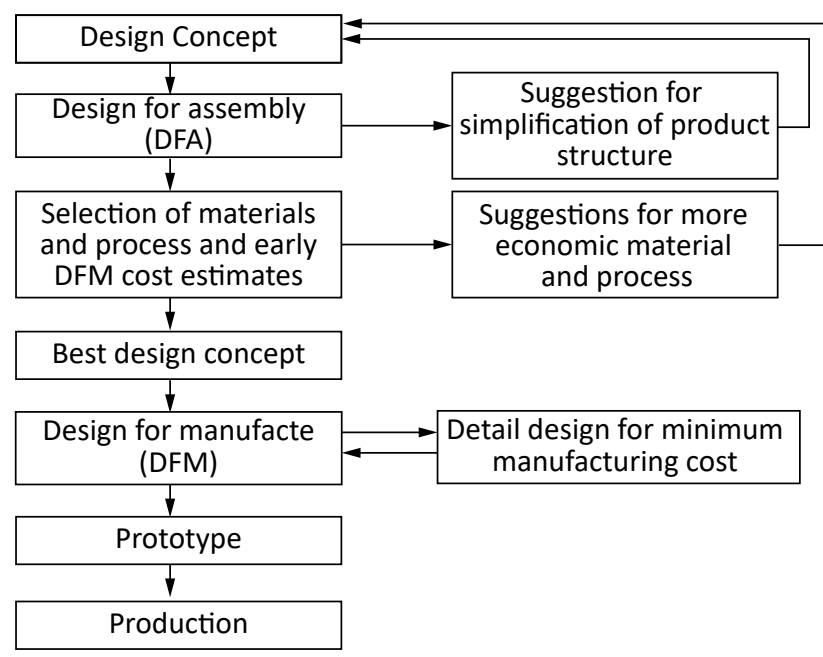

Picture 6. Application of DFMA in the process of a project. Source: Boothroyd et al. (1994) apud Barbosa (2012)

Design simplification for manufacturing and assembly helps in the final design definition. In this way, the student has all the information to create a prototype. However, its viability can only be measured by cost calculations.

\subsection{Project Cost}

Cost is an exploratory part of the reality of the project because good ideas have to be represented at simple costs. At first the cost is relieved with a design for separating the raw material and man hour used in each step. Picture 7 supports that the manager ensures that a person does not perform two tasks at the same time (Arijeloye et al., 2016).

By scheduling the resources for each activity, the project can be quoted. The point is to qualify its spending where each step adds up to the total. The representation is given in Picture 8. Where the top is the cost of design and the bottom of the prototype.

Although they represent the costs of project development, it is modified when the product begins to be developed in a production line and starts to process costs.

\section{RESULTS}

The process of product development in the classroom is very close to the PDP system developed by Rozenfeld (2006). The results span the theory of practice to design prototypes. Competitions are set up for the comparison between the project as presented in the second semester of 2015, see Picture 9.

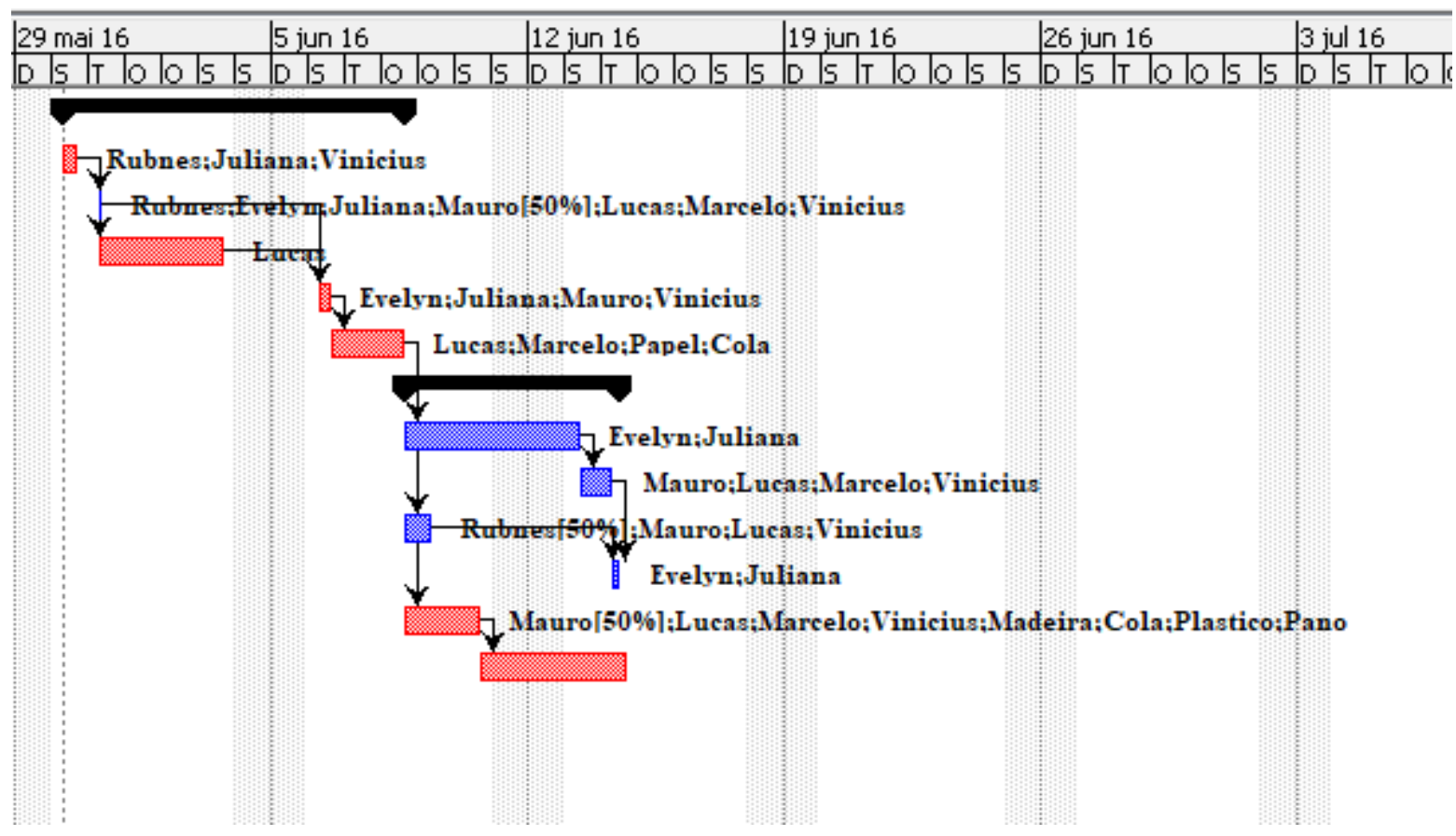

Picture 7. Gantt development for toys 

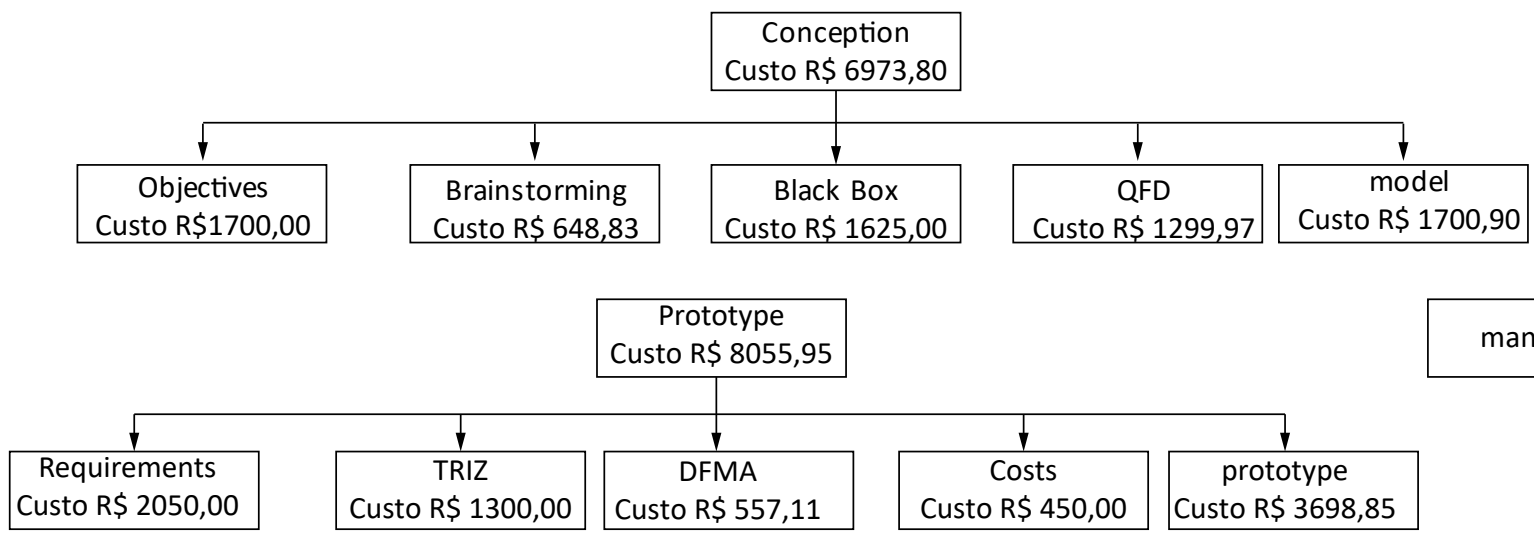

Picture 8. Project cost

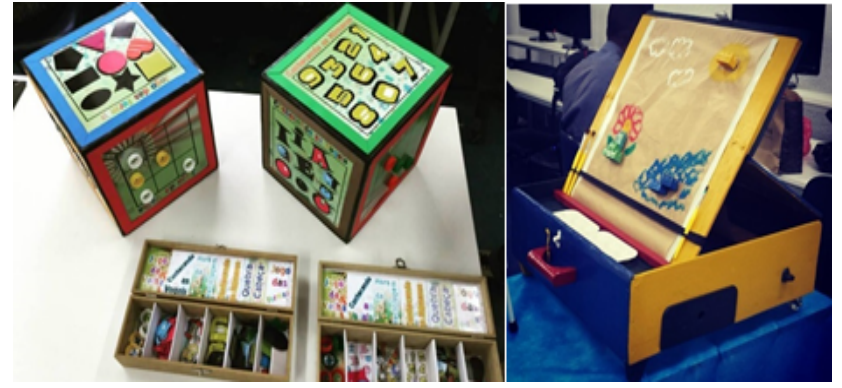

Picture 9. Winners of the first academic competition

The evolutions of the prototypes were visible. The maturity of the competition helps students in terms of their commitment to make a delivery and to disengage in the apprehension of getting a good grade. The results positively affected the student's average score. The combination of theory with practice and the movement of competitions encourages students to learn. The grades of the students had a significant increase in the assessments, as shown in Graph 1.

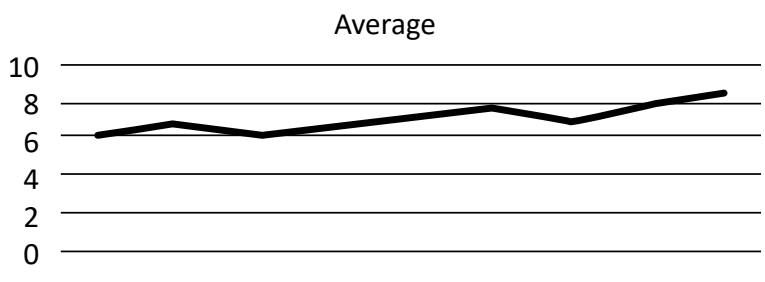

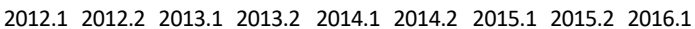

Graph 1. Students average.

It can be observed that from the semester 2015.2 there was a tendency for grades to grow.

\section{CONCLUSION}

The Product Design Process model, as evidenced by Rozenfeld (2006), can be developed in the classroom for product development and academic teaching. Some adaptations were made to evaluate engineering parameters, such as the TRIZ model.

The framework was created to relate the steps of creating a model through Brainstorming, Reverse Engineering, QFD and Design Project. The creation of the prototypes starts with the specifications of the engineering features through the Value Engineering followed by their improvement by the TRIZ methodology perfected for manufacturing and assembly with the DFMA and ending with feasibility with the development of costs.

The competition model represents a source of ideas because without the financial resources to boost the projects, the format to produce is the will to win. The model needs to be refined to generate a collaborative degree. The traditional format of student assessment through evidence becomes obsolete. The development of a project in the form of competition brings a purpose to students. The average turns into a detail.

To make project costs feasible the students need to use the maximum amount of recyclable resources. Search for alternative materials in order to adapt to the market makes the project inexpensive. The excess of innovation lowers the quality of delivery compromising the value added to the product.

Involving students in a competition which is not an expository class generates euphoria in academic development. Toy donation for poor kids generates an ethical commotion in the delivery of a product to society. The delivery of the students can generate an intangible value for professors and for the institution. 


\section{REFERENCES}

Arijeloye, B. T.; Aghimien, D. O.; Adegbembo, T. F. (2016). Reliability of preliminary cost estimates of educational building projects in a developing economy. Journal of Construction Engineering, Technology and Management, Vol. 6, No. 3, pp. 1-10.

Barbosa, G. F. (2012). Desenvolvimento de um modelo de análise para implantação de automação na manufatura aeronáutica orientado pelos requisitos das metodologias de projeto para excelência (DFX-Design For Excellence) e Produção Enxuta (Lean Manufacturing), Tese de doutorado, Universidade de São Paulo, São Paulo, SP.

Dym, C. L. et al. (2009), Introdução à engenharia: uma abordagem baseada em projeto, Bookman, Porto Alegre, RS.

Fernandes, J. N. S. (2013), Aplicação da metodologia TRIZ em empresas industriais, Dissertação de mestrado, Faculdade de Ciências e Tecnologia, Universidade NOVA de Lisboa, Lisboa.

Gomes Filho, A. C.; Rautenberg, S. (2015), Ontologias para a Teoria TRIZ: Uma necessidade?, Ciências e Cognição, Vol. 20, No. 2, pp. 270-276.
Li, Y.; Van't Veld, K. (2015), Green, greener, greenest: Eco-Label gradation and competition. Journal of Environmental Economics and Management, Vol. 72, pp. 164-176.

Peinado, J.; Graeml, A. R. Administração da produção. Operações industriais e de serviços, UnicenP, Curitiba, PR.

Rozenfeld, H. et al. (2006), Gestão de desenvolvimento de produtos - Uma referência para a melhoria do processo, Saraiva, São Paulo, SP.

Santos, L. M. A. L. et al. (2016), Melhorias no fluxo interno de informações a partir da aplicação da ferramenta QFD. Revista Gestão Industrial, Vol. 12, No. 3, pp. 165-180.

Schlender, B.; Tetzeli, R. (2015), Como Steve Jobs virou Steve Jobs, Intrínseca, Rio de Janeiro, RJ.

Silva, D. E. N. (2014), O design industrial e as engenharias: Uma possibilidade de integração por intermédio da engenharia reversa, Tese de doutorado, Faculdade de Arquitetura, Artes e Comunicação, Universidade Estadual Paulista Júlio de Mesquita Filho, São Paulo, SP.

Received: 18 Jan 2018

Approved: 25 Jul 2018

DOI: 10.14488/BJOPM.2018.v15.n4.a2

How to cite: Walker, R. A.; Gutierrez, R. H.; Santos, M. et al. (2018), “Academic competition for prototype development", Brazilian Journal of Operations \& Production Management, Vol. 15, No. 4, pp. 481-489, available from: https://bjopm.emnuvens.com.br/bjopm/article/view/443 (access year month day). 